\title{
Engineering Properties of Permeable Polymer Concrete Using Bottom Ash and Recycled Coarse Aggregate
}

\author{
Sung, Chan Yong* - Kim, Jong Hyouk**
}

\begin{abstract}
Permeable polymer concretes can be applied to roads, sidewalks, river embankment, drain pipes, conduits, retaining walls, yards, parking lots, plazas, interlocking blocks, etc. This study was to explore a possibility of using bottom ash as filler and recycled coarse aggregate of industrial by-products for permeable polymer concrete. The tests carried out at $20 \pm 1{ }^{\circ} \mathrm{C}$ and $60 \pm 2 \%$ relative humidity. At 7 days of curing, unit weight, void ratio, compressive and flexural strength and coefficient of permeability ranged between 1,652 1,828 $\mathrm{kgf} / \mathrm{m}^{3}, 15 \sim 29 \%, 18.2 \sim 24.5 \mathrm{MPa}, 6.4 \sim 8.4 \mathrm{MPa}$, and $6.8 \times 10^{-2} \sim 1.7 \times 10^{-1} \mathrm{~cm} / \mathrm{s}$, respectively. It was concluded that the bottom ash and recycled coarse aggregate can be used in the permeable polymer concrete.
\end{abstract}

Keywords : Permeable polymer concrete, Bottom ash, Recycled coarse aggregate, Unit weight, Void ratio, Strengths, Coefficient of permeability

\section{Introduction}

Demand for concrete material supply has been widening with the rapid growth of the construction industry. Supply of natural materials from river beds and mountains are not sufficient. Environmental problems associated with the material collection from river beds by dredging

* Professor, Division of Bio-Resources Engineering, College of Agriculture and Life Sciences, Chungnam National University

** Department of Agricultural Engiceering, Graduate School, Chungnam National University

* Corresponding author. Tel.: +82-42-821-5798

Fax: $+82-42-821-8877$

E-mail address: cysung(@)cnu.ac.kr and from mountains by excavation have caused strong protests from environmentalists. With the growth of construction industry, the supply of materials in the construction industry was been pressing problems to solve in the near future. Application of industrial by-products of concrete has widely increased, and recent studies have found to the excellent compatibility between those industrial by-products and polymers. ${ }^{\text {7).9).10) }}$

The use of polymer concrete as an alternative to cement concrete products has been increasing because of its super physical and mechanical properties, chemical resistance, durability, strong adhesion and rapid curing. ${ }^{2)}$

This study initiated to find a way to reuse 
industrial by-products as precious resource. A way to reuse the industrial by-products is to use them as construction material. The objectives of this study are to find a way to reuse bottom ash as filler and recycled coarse aggregate as aggregate.

\section{Materials}

\section{Unsaturated Polyster Resin}

An ortho phthalate-type unsaturated polyster resin with an accelerator was used in this study, and its general properties are shown in Table 1.

Table 1 General properties of unsaturated polyester resin

\begin{tabular}{c|c|c|c}
\hline $\begin{array}{c}\text { Density } \\
\left(\mathrm{g} / \mathrm{cm}^{2}, 20^{\circ} \mathrm{C}\right)\end{array}$ & $\begin{array}{c}\text { Viscosity } \\
\left(20^{\circ} \mathrm{C}, \text { poise }\right)\end{array}$ & $\begin{array}{c}\text { Styrene } \\
\text { content }(\%)\end{array}$ & $\begin{array}{c}\text { Acid } \\
\text { value }\end{array}$ \\
\hline 1.12 & 3.5 & 37.2 & 26.5 \\
\hline
\end{tabular}

\section{Hardener}

Hardener was used for normal hardening and its general properties are shown in Table 2.

Table 2 General properties of hardener

\begin{tabular}{c|c|c}
\hline Component & $\begin{array}{c}\text { Density } \\
\left(\mathrm{g} / \mathrm{cm}^{3}, 20{ }^{\circ} \mathrm{C}\right)\end{array}$ & $\begin{array}{c}\text { Active oxygen } \\
(\%)\end{array}$ \\
\hline $\begin{array}{c}\text { MEXPO 55\% } \\
\text { DMP 45\% }\end{array}$ & 1.13 & 10.0 \\
\hline
\end{tabular}

\section{Aggregates}

Aggregates used were recycled coarse aggregate and natural fine aggregate. The aggregates were dried at $100 \pm 5^{\circ} \mathrm{C}$ for one day before use.
Physical properties of the aggregates are shown in Table 3.

Table 3 Physical properties of aggregates

\begin{tabular}{c|c|c|c|c|c}
\hline Item & $\begin{array}{c}\text { Size } \\
(\mathrm{mm})\end{array}$ & $\begin{array}{c}\text { Unit } \\
\text { weight } \\
\left(\mathrm{kgf} / \mathrm{m}^{3}\right)\end{array}$ & $\begin{array}{c}\text { Density } \\
\left(\mathrm{g} / \mathrm{cm}^{2},\right. \\
\left.20^{\circ} \mathrm{C}\right)\end{array}$ & $\begin{array}{c}\text { Absorption } \\
\text { rate }(\%)\end{array}$ & $\begin{array}{l}\text { Fineness } \\
\text { modulus }\end{array}$ \\
\hline $\begin{array}{c}\text { Recycled } \\
\text { coarse } \\
\text { aggregate }\end{array}$ & $5 \sim 10$ & 1,562 & 2.62 & 1.87 & 6.49 \\
\hline $\begin{array}{c}\text { Natural } \\
\text { fine } \\
\text { aggregate }\end{array}$ & $0.6 \sim 5$ & 1.500 & 2.59 & 1.12 & 2.82 \\
\hline
\end{tabular}

4. Filler

Bottom ash was used in this study because it is relatively cheap and easy to buy. Filler was dried at $100 \pm 5{ }^{\circ} \mathrm{C}$ for one day before use. Physical properties and chemical composition of the filler are shown in Table 4 and Table 5.

Table 4 Physical properties of bottom ash

\begin{tabular}{c|c|c|c|c}
\hline $\begin{array}{c}\text { Density } \\
\left(\mathrm{g} / \mathrm{cm}^{3}\right. \\
\left.20^{\circ} \mathrm{C}\right)\end{array}$ & $\begin{array}{c}\text { Specific } \\
\text { surface } \\
\left(\mathrm{cm}^{2} / \mathrm{g}\right)\end{array}$ & $\begin{array}{c}\text { Unit weight } \\
\left(\mathrm{kgf} / \mathrm{m}^{3}\right)\end{array}$ & $\begin{array}{c}\text { Grain size } \\
(\mathrm{mm})\end{array}$ & Color \\
\hline 2.42 & 2,300 & 1,200 & $\langle 0.15$ & Gray \\
\hline
\end{tabular}

Table 5 Chemical composition of bottom ash

\begin{tabular}{c|c|c|c|c|c|c|c|c}
\multicolumn{9}{|c}{} \\
\hline $\mathrm{SiO}_{2}$ & $\mathrm{Al}_{2} \mathrm{O}_{3}$ & $\mathrm{~K}_{2} \mathrm{O}$ & $\mathrm{Fe}_{2} \mathrm{O}_{3}$ & $\mathrm{Na}_{2} \mathrm{O}$ & $\mathrm{MgO}$ & $\mathrm{CaO}$ & $\mathrm{TiO}_{2}$ & lg.loss \\
\hline 46.1 & 18.7 & 0.82 & 10.2 & 0.97 & 1.80 & 18.8 & 0.09 & 0.62 \\
\hline
\end{tabular}

\section{Mix Proportions of Permeable Polymer Concrete}

After many preliminary tests, six mix proportions were tried to determine an optimum mix 
proportions of permeable polymer concretes using bottom ash and recycled coarse aggregate contents of unsaturated polyester resin based binder with the hardening system, filler and aggregates were fixed as seen in Table 6 .

Table 6 Mix proportions of permeable polymer concrete

(Unit: wt, \%)

\begin{tabular}{|c|c|c|c|c|c|c|}
\hline \multirow[b]{2}{*}{$\begin{array}{l}\text { Mix } \\
\text { type }\end{array}$} & \multicolumn{2}{|c|}{ Binder } & \multicolumn{2}{|c|}{ Aggregate } & \multirow{2}{*}{$\begin{array}{c}\text { Filler } \\
\text { Bottom } \\
\text { ash }\end{array}$} & \multirow[b]{2}{*}{ Total } \\
\hline & $\begin{array}{l}\text { Unsatu- } \\
\text { rated } \\
\text { polyester } \\
\text { resin }\end{array}$ & Hardener & $\begin{array}{l}\text { Natural } \\
\text { fine }\end{array}$ & $\begin{array}{l}\text { Recyled } \\
\text { coarse }\end{array}$ & & \\
\hline $\mathrm{BPPC0}$ & 6.94 & 0.07 & 16,16 & 76.83 & 0.00 & 100 \\
\hline $\mathrm{BPPCl}$ & 7.14 & 0.07 & 15.38 & 75.41 & 2.00 & 100 \\
\hline $\mathrm{BPPC2}$ & 7.43 & 0.07 & 13.89 & 74.61 & 4.00 & 100 \\
\hline $\mathrm{BPPC} 3$ & 7.71 & 0.08 & 12.99 & 73.22 & 6.00 & 100 \\
\hline $\mathrm{BPPC4}$ & 8.00 & 0.08 & 11.79 & 72.13 & 8.00 & 100 \\
\hline BPPC5 & 8.34 & 0.08 & 11,13 & 70.40 & 10,00 & 100 \\
\hline
\end{tabular}

\section{Manufacture and Curing of Specimens}

Specimens were manufactured according to the Korean Standard Testing Methods, KS F 2419 (Specimen preparation methods for strength measure of polyester resin concrete). Permeable polymer concretes were mixed by using a high performance concrete mixer. Two types of specimen, i.e., cylindrical and block specimens, were made depending on test. Specimens were molded by putting permeable polymer concrete into a cylindrical and block molds, and the molds were put on a table vibrator and compacted sufficiently by vibration for three minutes. All the specimens were demolded after curing at a room temperature of $20 \pm 1{ }^{\circ} \mathrm{C}$ for three hours, and cured again at $20 \pm 1{ }^{\circ} \mathrm{C}$ and $60 \pm 2 \%$ relative humidity for up to 7 days.

\section{Methodology}

\section{Unit Weight}

Unit weight of permeable polymer concrete was evaluated from the following equation.

$$
\mathrm{UW}=\frac{W_{c}}{V_{c}}
$$

where, UW is unit weight $\left(\mathrm{kgf} / \mathrm{m}^{3}\right), W_{C}$ is weight and $\mathrm{Vc}$ is volume of permeable polymer concrete.

\section{Void Ratio}

For the void ratio test, a specimen of $\varnothing 100 x$ $200 \mathrm{~mm}$ was made of the porous polymer concrete. It was inserted in the plastic mold and filled with water. The void ratio was calculated by measuring the volume of water.

\section{Compressive strength}

Compressive strength test of specimen was carried out according to the KS F 2481(Compressive strength test method for polyester resin concrete). Strength test was carried out at the 7 days of curing, and the size of cylindrical was $\varnothing 100 \times 200 \mathrm{~mm}$.

\section{Flexural Strength}

Flexural strength test of specimen was carried out according to the KS F 2482 (Flexural strength test method for polymer resin concrete). Strength test was carried out at the 7 days of curing, and the size of beam specimens was $60 \times 60 \times 240 \mathrm{~mm}$. 


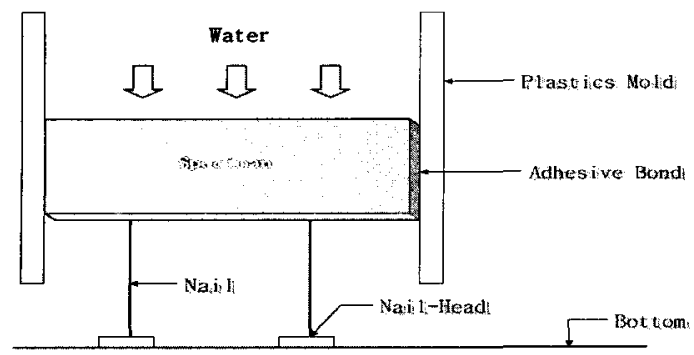

Fig. 1 Permeability coefficient testing apparatus

\section{Coefficient of Permeability}

The water level was about $5 \mathrm{~cm}$, the amount of permeated water was $10 \ell$, and the experiments were repeatedly performed 5 times. Coefficient of permeability was measured by volume of permeated water $(\mathrm{cm} / \mathrm{s})$. The size of beam specimens was $240 \times 240 \times 40 \mathrm{~mm}$. The permeability coefficient testing apparatus for permeable polymer concretes used in this study is shown in Fig. 1.

\section{Results and Discussion}

\section{Unit Weight}

Table 7 shows the results of unit weight tests on permeable polymer concrete. Unit weight of permeable polymer concrete ranged from 1,652 $\sim 1,828 \mathrm{kgf} / \mathrm{m}^{3}$ and it was largely dependent upon the mix proportions, and it was decreased from 20 to $28 \%$ than that of normal cement concrete $\left(2,300 \mathrm{kgf} / \mathrm{m}^{3}\right)$. Unit weight of permeable polymer concrete was mainly affected by coefficient of permeability. ${ }^{8)}$

Unit weight is increased with increasing the content of bottom ash. The highest unit weight was shown by $100 \%$ filled bottom ash and the
Table 7 Test results of permeable polymer concrete

\begin{tabular}{c|c|c|c|c|c}
\hline $\begin{array}{c}\text { Mix } \\
\text { type }\end{array}$ & $\begin{array}{c}\text { Unit } \\
\text { weight } \\
\left(\mathrm{kgf} / \mathrm{m}^{3}\right)\end{array}$ & $\begin{array}{c}\text { Void } \\
\text { ratio } \\
(\%)\end{array}$ & $\begin{array}{c}\text { Strength }(\mathrm{MPa}) \\
\text { pressive }\end{array}$ & $\begin{array}{c}\text { Com- } \\
\text { Coefficient } \\
\text { of permea- } \\
\text { bility } \\
(\mathrm{cm} / \mathrm{s})\end{array}$ \\
\hline BPPC0 & 1,652 & 29 & 18.2 & 6.4 & $1.7 \times 10^{-1}$ \\
\hline BPPC1 & 1,666 & 28 & 18.8 & 6.6 & $1.4 \times 10^{-1}$ \\
\hline BPPC2 & 1,687 & 26 & 19.7 & 7.4 & $1.1 \times 10^{-1}$ \\
\hline BPPC3 & 1,711 & 23 & 21.3 & 7.7 & $1.0 \times 10^{-1}$ \\
\hline BPPC4 & 1,738 & 19 & 23.9 & 8.1 & $8.3 \times 10^{-2}$ \\
\hline BPPC5 & 1,828 & 15 & 24.5 & 8.4 & $6.8 \times 10^{-2}$ \\
\hline
\end{tabular}

lowest unit weight was shown by $0 \%$ filled bottom ash as filler for permeable polymer concrete.

\section{Void Ratio}

Void ratios of permeable polymer concrete are shown in Table 7 and Fig. 2. Void ratio ranged $15 \sim 29 \%$, which are approximately satisfied for planting void ratio $20 \sim 30 \%$.

Void ratio is decreased with increasing the content of bottom ash and are decreased 3.4 $48.3 \%$ according to the content used of bottom ash.

The highest void ratio was shown by 0\% filled

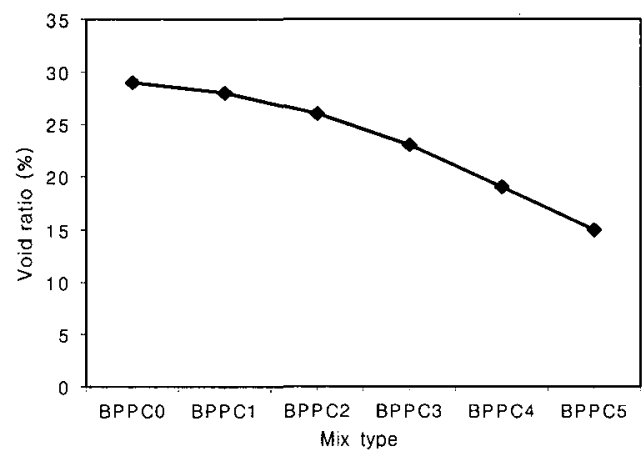

Fig. 2 Comparison of void ratio by mix type 
bottom ash and the lowest void ratio was shown by $100 \%$ filled bottom ash as filler for permeable polymer concrete.

\section{Compressive Strength}

Strength development of permeable polymer concrete was assumed to be related to the content of bottom ash as filler. Thus, strength tests were performed with respect to the different content of filler. Table 7 and Fig. 3 shows the results of compressive strength tests. The highest compressive strength was achieved by $100 \%$ filled bottom ash as filler, and the choice of filler is very important. ${ }^{1)}$

Compressive strength ranged $18.2 \sim 24.5 \mathrm{MPa}$ and is increased with increasing the content of bottom ash and are increased with 3.2 34.6\% according to the content used of bottom ash.

It is thought that such result is due to increasing the coating thickness of the aggregates by binder content increased because the mix proportion of the binder was the most important factor for the strength of the permeable polymer concrete.

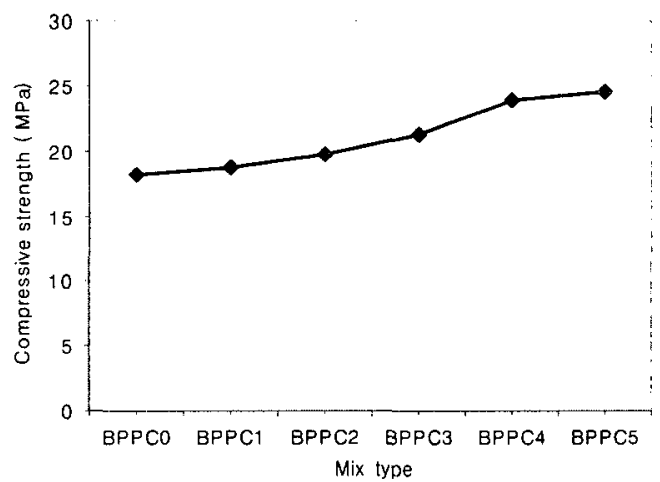

Fig. 3 Comparison of compressive strength by $\mathrm{mix}$ type
Compressive strength was greater than the standard compressive strength $18 \mathrm{MPa}$ for permeable concrete pavement. It is expected that the utilization of recycled coarse aggregate and bottom ash for the manufacture of permeable polymer concrete for permeable pavement will be useful.

\section{Flexural Strength}

Flexural strength was used for the standard design strength for pavement plates, concrete pipe and concrete piles subject to flexural stress such as roads and runways.

The requirements on the flexural strength are presented for the concrete plates and concrete blocks for sidewalk and driveways. Flexural strength of permeable polymer concrete are shown in Table 7.

The highest flexural strength was achieved by $100 \%$ filled bottom ash as filler.

Flexural strength ranged 6.4 8.4 $\mathrm{MPa}$ and is increased with increasing the content of bottom ash and are increased with $3.1 \sim 31.2 \%$ according to the content used of bottom ash as filler. Flexural strength was interrelated with the compressive strength and coefficient of permeability. $^{9)}$

It is expected that the utilization of recycled coarse aggregate and bottom ash for permeable polymer concrete pavement and permeable block will be useful.

Accordingly, the application of permeable polymer concrete structures are subject to flexure stress can be used. 


\section{Coefficient of Permeability}

Table 7 and Fig. 4 show the coefficient of permeability of permeable polymer concrete. Measured coefficient of permeability of permeable polymer concrete was in the range of $6.8 \times 10^{-2} \sim 1.7 \times 10^{-1} \mathrm{~cm} / \mathrm{s}$ and it was largely dependent upon the mix proportions. In all mix proportions, it was greater than the standard permeability coefficient $1 \times 10^{-2} \mathrm{~cm} / \mathrm{s}$ for permeable concrete pavement. ${ }^{5}$ )

The highest coefficient of permeability was shown by $0 \%$ filled bottom ash and the lowest coefficient of permeability was shown by $100 \%$ filled bottom ash as filler for permeable polymer concrete.

It proved that the permeability of permeable polymer concrete was superior. Accordingly, these permeable polymer concretes can be used for structures which needs appropriate strength and coefficient of permeability.

In the permeable concrete pavement, the greater permeability coefficient is advantageous. The permeating capacity of the drainage layer must be considered for the construction of permeable pavement, and the mutual permeating

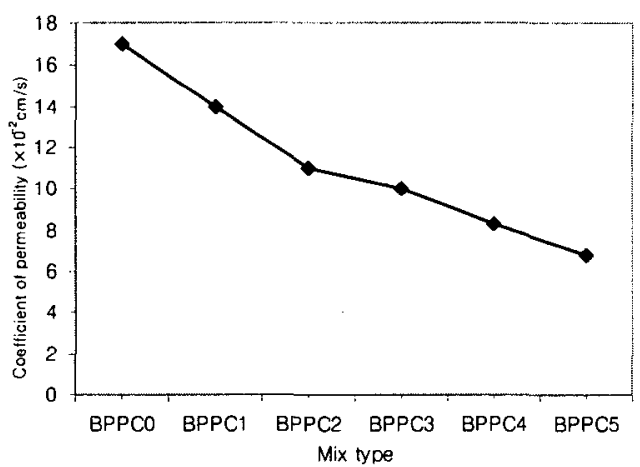

Fig. 4 Comparison of coefficient of permeability by mix type. capacity of permeable blocks and drainage layer must be reflected in the mix proportions.

\section{Conclusions}

This study was performed to evaluate the engineering properties of permeable polymer concrete using bottom ash, recycled coarse aggregate, unsaturated polyester resin and hardener. The following conclusions were drawn from the test results;

1. Unit weight of permeable polymer concrete ranged from 1,652 to $1,828 \mathrm{kgf} / \mathrm{m}^{3}$ and it was largely dependent upon the mix proportions. It was mainly affected by coefficient of permeability.

2. Void ratio was in the range of $15 \sim 29 \%$, which are satisfied for planting void ratio 20 $30 \%$ and are decreased $3.4 \sim 48.3 \%$ according to the content used of bottom ash.

3. Compressive strength of permeable polymer concrete ranged between 18.2 24.5 MPa. The highest compressive strength was achieved by $100 \%$ filled bottom ash and is increased with increasing the content of bottom ash as filler. Compressive strength was greater than the standard compressive strength $18 \mathrm{MPa}$ for permeable concrete pavement. It is expected that the utilization of recycled coarse aggregate and bottom ash for the manufacture of permeable polymer concrete for permeable pavement will be useful.

4. Flexural strength ranged between $6.4 \sim 8.4$ $\mathrm{MPa}$ and is increased with increasing the content of bottom ash. Flexural strength was interrelated with the compressive strength and coefficient of permeability. It is expected that the utilization of 
recycled coarse aggregate and bottom ash for permeable polymer concrete pavement and permeable block will be useful.

5. Coefficient of permeability of permeable polymer concrete was in the range of $6.8 \times 10^{-2} \sim$ $1.7 \times 10^{-1} \mathrm{~cm} / \mathrm{s}$ and it was greater than the standard permeability coefficient $1 \times 10^{-2} \mathrm{~cm} / \mathrm{s}$ for permeable concrete pavement. These permeable polymer concretes can be used for structures which needs appropriate strength and coefficient of permeability.

\section{References}

1. Aguado. D. C. A., A. Martinez and J. M. Sella., 1983, Effect of different factors in mixing and placing of polymer concrete, proceedings of the 4th ICPIC, Technische Hochschule Darmstadt, Germany: 299-303.

2. Fowler, D. W., 1987, Current status of polymers in concrete, Proceedings of the 5th ICPIC, Bighton Polytechnic, U.K: 3-7.

3. Japan Concrete Institute, 1995, Eco-concrete research committee report, $J C I$, Tokyo.

4. Paturoev, V. V., 1986, Recommendations on polymer concrete mix design, NIZHB, Moscow: 18.

5. Pack, P. W., C. Y. Sung, 2004, Engineering properties of Eco-permeable polymer con- cretes using blast furnace slag powder and stone dust, Journal of the Korean Society of Agricultural Engineers 46(7): 47-53. (in Korean)

6. Sung, C. Y., 1995, Mechanical characteristics of permeable polymer concrete, Proceedings of the '95 Japan and Korea Joint Seminar, Tottori University, Japan: 32-35. (in korean)

7. Sung, C. Y and H. J. Jung., 1996, Engineering properties of permeable polymer concrete with stone dust and fly ash, Journal of the Korean Society of Agricultural Engineers 38(4): 147-154. (in Korean)

8. Sung. C. Y., K. S. Yeon., N. H. Ryu., K. S. Kim and J. K. Min., 2001, Development of agriculture hydraulic structure for water collecting and draining, Journal of the Korean Society of Agricultural Engineers 43(2): 105111. (in Korean)

9. Sung, C. Y and J. N. Youn., 2006, Permeability and strength properties of permeable polymer concretes using rice husk ash, 5th Asian Symposium on Polymers in Concrete, India, Chennai: 411-418. (in Korean)

10. Yeon, K. S., K. W. Kim., K.S. Kim and K. H. Kim., 1993, Effects of fillers on mixing and mechanical preperties of polymer concrete, Journal of the Korean Society of Agricultural Engineers 35(2): 81-91. (in Korean) 